\title{
DVASINGUMO VERTINIMAS: HUMANISTINIO DVASINGUMO APRAŠO KŪRIMAS IR VALIDAVIMAS
}

\author{
Simona Kontrimienè \\ Vilniaus universitetas
}

\begin{abstract}
Anotacija
Dvasingumas yra esminė žmogaus vara su daugybe ypatingą mąstymą lemiančių išraiškos formų, leidžiančiu pasiekti aukštą sąmoningumo ir informacijos integravimo lygmenị. Straipsnyje pristatomas Humanistinio dvasingumo modelis ir jo pagrindu sukurtas dvasingumo matas - Humanistinio dvasingumo aprašas. Skiriami trys modelio komponentai: savęs aktualizavimas, transcendavimas ir gyvenimo prasmès (iš)gryninimas, jų apraiškos, apraiškas apibrèžiantys rodikliai ir jų raiškos empiriniai požymiai. Humanistinio dvasingumo aprašas, susidedantis iš trijų modelio komponentus atitinkančių skalių, validuotas tyrimu $(N=331)$, kuriuo atskleista, kad instrumentas pasižymi tinkamomis psichometrinėmis savybėmis - turinio ir konstruktų validumu bei teiginių vidinio suderintumo ir pakartotinio testavimo patikimumu, todèl gali būti naudojamas moksliniuose tyrimuose kaip tinkamas dvasingumo vertinimo matas.

PAGRINDINIAI ŽODŽIAI: dvasingumas, Humanistinio dvasingumo modelis, Humanistinio dvasingumo aprašas, savęs aktualizavimas, transcendavimas, gyvenimo prasmè.
\end{abstract}

\begin{abstract}
Spirituality is a basic human drive with diverse forms of expression that make for unique patterns of thinking consonant with an advanced level of cognition and integration of information. The paper features the Humanistic Spirituality Model, which captures the essential dimensions of humanistic spirituality through three components: self-actualisation, transcendence and ultimate meaning in life. The Humanistic Spirituality Inventory (HSI), a measure of spirituality developed on the basis of the Humanistic Spirituality Model, contains three scales corresponding to the three model components. According to the results of the HSI validation study $(N=331)$, the instrument has good psychometric properties, i.e. adequate content and construct validity as well as satisfactory internal consistency and test-retest reliabilities, which makes it a proper spirituality research measure.

KEY WORDS: spirituality, Humanistic Spirituality Model, Humanistic Spirituality Inventory, selfactualisation, transcendence, meaning in life.
\end{abstract}

DOI: http://dx.doi.org/10.15181/tbb.v79i3.1889

\section{Ivadas}

Dvasingumas - tai sąvoka, kurios prasmę kiekvienas mūsų tariamės žinantys, kol nereikia jos tiksliai apibrěžti. Galima neabejoti tik tuo, kad dvasingumas yra aukštu žmogaus aspiracijų realizavimo sąlyga ir esminè žmogaus vara su daugybe ypatingą mąstymą lemiančių išraiškos formų (Miller, Nakagawa, 2002; Sinetar, 2000).

Užsienio šalyse pastaraisiais dešimtmečiais dvasingumo klausimas vis dažniau grąžinamas ị rimtą akademinị diskursą, gerokai išaugo empirinių dvasingumo tyrimų skaičius (Moberg, 2002; Kapuscinski, Masters, 2010). 
Lietuvoje dvasingumą daugiausia tiria ugdymo mokslų atstovai (Jovaiša, 1998; Bitinas, 2004; Aramavičiūtė, 2005; 2010; Martišauskiené, 2004; 2008). Dvasingumo samprata čia neatsiejama nuo aksiologijos, nes siekiant dvasinės brandos, kyla užduotis atrasti veiksmingų būdų internalizuoti aukščiausias dvasines vertybes, kurios padètų žmogui orientuotis savyje ir pasaulyje, užsiimti refleksija (retrospekcija, introspekcija, anticipacija) ir saviaukla, ugdyti savimonę.

Tačiau net ir pripažizstant, kad dvasingumo pamatas yra asmens dvasinių vertybių sistema, ne mažiau svarbu ịsigilinti ị tai, kokie asmenybès savumai lemia dvasingumą, kitaip, kokie yra sudètiniai dvasingumo komponentai. Mūsų atlikta dvasingumo reiškinio analizè turinio komponentų aspektu atskleidè, kad universalios šio reiškinio definicijos nèra ir turbūt negali būti, nes dvasingumą tyrinèjantys autoriai jo sampratoms suteikia skirtingas prasmes. Užsienio literatūroje ị dvasingumo sampratas galima žiūrèti kaip ị esančias skirtingose kontinuumo pozicijose: vienoje pusēje išsidèsčiusios tos, kurios pagrịstos religiniais ir teistiniais idealais (žr. Thatcher, 1996), kitoje - sekuliarios humanistinès, egzistencialistinès sampratos (žr. Hay, Nye, 2006; Elkins, 2015), jų pagrindu dažnai kuriami dvasingumo modeliai ir matai. Šiame straipsnyje pateikiama šiuolaikinių dvasingumo modelių apžvalga ir mūsų siūlomas svarbiausius bendrus dvasingumo vardiklius apimantis Humanistinio dvasingumo modelis, kurio pagrindu sudarytas ir straipsnyje pristatomu tyrimu validuotas humanistinio dvasingumo matas - Humanistinio dvasingumo aprašas.

Humanistinès psichologijos atstovų K. J. Schneider'io, J. F. T. Bugental'io ir J. F. Pierson'o teigimu, humanistinè prieiga „išlieka psichinę ir dvasinę pilnatvę, visuminę pasaulèžiūrą, mąstymo gelmę suteikiančia jèga" (Schneider, Bugental, Pierson, 2015, p. xvi). J. Vasconcell'os (2015) žodžiais, naujausia žmonijos revoliucija numato tai, kas svarbiausia, - savęs aktualizavimą, ir kaip tik humanistinis požiūris ị žmogaus savastị turètų tapti universalia mūsų laikų ir gyvenimo vizija.

Tyrimo tikslas - validuoti siūlomo Humanistinio dvasingumo modelio pagrindu sukurtą dvasingumo matą, Humanistinio dvasingumo aprašą.

Siekiant užsibrèžto tikslo, sprendžiami šie uždaviniai:

1. Apželgti šiuolaikinius dvasingumo modelius turinio komponentų aspektu.

2. Atliktos dvasingumo komponentų analizès aprèptyje sukurti teorinį-empirinị dvasingumo raiškos modelị.

3. Dvasingumo modelio pagrindu sudaryti dvasingumo tyrimo instrumentą dvasingumo aprašą.

4. Atlikti dvasingumo aprašo validavimo - turinio ir konstruktų validumo, teiginių vidinio suderintumo ir pakartotinio testavimo patikimumo - tyrimą.

Metodologinè tyrimo prieiga grindžiama postpozityvizmo ir humanistinès psichologijos paradigmomis. 
Tyrimo metodai: sisteminè mokslinès literatūros analizè, sintezè, interpretavimas ir vertinimas; kiekybinès apklausos ir statistinė duomenų analizè.

\section{1. Šiuolaikiniai dvasingumo modeliai}

Šiandien mokslinejje literatūroje pateikiama daug dvasingumo modelių, matų ir su dvasingumu siejamų konstruktų (žr. Kapuscinski, Masters, 2010; MacDonald, Friedman, Kuentzel, 1999), įspūdinga yra šiu modelių, taip pat ir dvasingumo konceptualizacijų, ịvairovè. Kai kuriuose jų dvasingumas apibrēžiamas kaip vienmatis (pvz., Kass ir kt., 1991; Corrington, 1989), kituose - kaip daugiamatis konstruktas (pvz., PSO, 1998; Howden, 1992; MacDonald, 2009). Daugiamačiuose modeliuose (kurie, beje, tapo populiaresni paskutini praejjusio amžiaus dešimtmetị) išskiriamų komponentų skaičius varijuoja nuo dviejų (pvz., Ellison, 1983) iki net aštuoniolikos (Pasaulio sveikatos organizacijos (1998) modelis). Klaidina tai, kad siūlomų komponentų ir juos sudarančiu subkomponentų apibrēžtys paskiruose modeliuose sutampa tik iš dalies ir tai paaiškina, kodèl iki šiol nesukurtas bendras dvasingumo modelis ir tyrejams tenka (pasitelkus savają logiką) vadovautis kuriuo nors iš jau sukurtų modelių arba kurti naujus. 1-oje lentelèje pristatomi šešių pagrindinių literatūroje aptariamų daugiamačių dvasingumo modelių komponentai.

Iš pateiktos dvasingumo modelių išsklaidos matyti, kad mokslinèje literatūroje nesilaikoma bendros nuomonès dèl dvasingumo turinio, todèl ir modelių komponentai gerokai skiriasi, be to, čia nèra nè vieno komponento, kuris būtų vienodai îvardytas ir ịtrauktas ị visus šešis modelius. Tačiau dera pažymèti, kad visus modelius sieja viena bendrybè - tai, kad juose pripažistama tikejimo aukštesniaja jèga svarba, nors šis komponentas įvardijamas skirtingai: kaip transcendavimo dimensija (Elkins ir kt., 1988), transcendavimas (Howden, 1992), pilnatvè maldoje (Piedmont, 1999; 2001), aukštesniosios jègos pripažinimas (Wolman, 2001), religingumas (MacDonald, 2000) arba transcendavimas ir asmeniniai religiniai ịsitikinimai (PSO, 1998).

Dar vienas komponentas, ịtrauktas ị keturis iš šešių modelių, yra gyvenimo prasmé, nors PSO modelyje tai nèra atskiras komponentas, o tik transcendavimo domeno subkomponentas, D. A. MacDonald'o modelyje ji pavadinta kiek kitaip - egzistencine gerove. Kiti modeliuose skiriami dvasingumo komponentai įvardijami skirtingai, nors juose galima įžvelgti asmens susitelkimo, mąstymo gelmès, platumo ir brandumo, nesavanaudiško tiesimosi ị kitą žmogų bei kuriamos vidinès ir gyvenimo gerovès motyvus - tai, be ko negali reikštis asmens dvasingumas. Visi šie svarbiausi komponentai ịtraukti ị mūsų siūlomą humanistinio dvasingumo modeli. 
Simona Kontrimienè

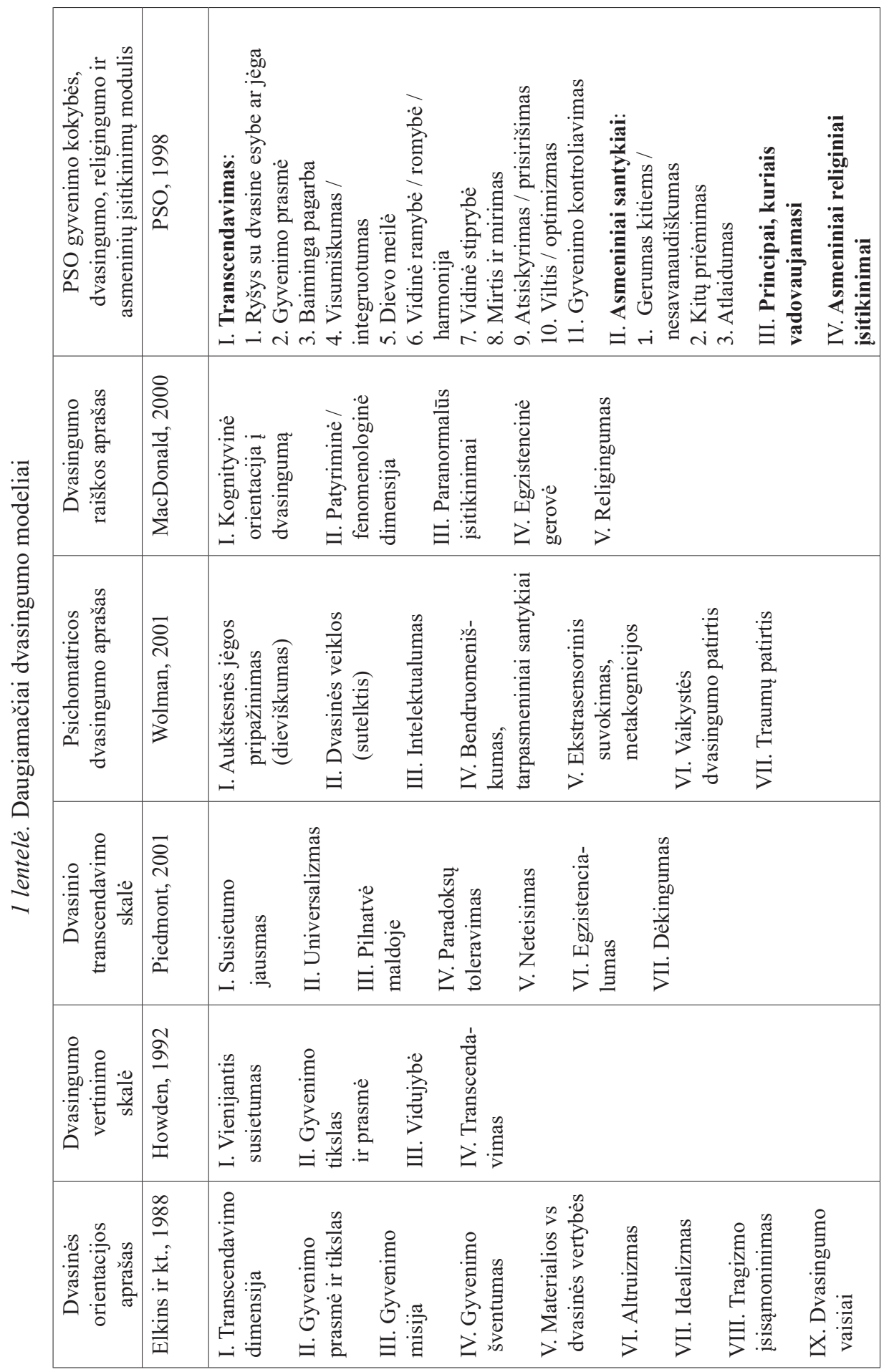




\section{Teorinis-empirinis humanistinio dvasingumo modelis}

Mūsų plètojama sakralaus humanistinio dvasingumo prieiga numato žmogaus, žinių ir žinojimo tobulèjimą, žmogaus savęs aktualizavimo ir transcendavimo ịgalintą virsmą bei gyvenimą vadovaujantis gilia tikejjimo ir vidinès darnos įkvejpta gyvenimo prasmès samprata. Prieigos pamatas - humanistinès filosofijos (Humanist Manifestos I, II, III, 2003) ir humanistinès psichologijos (Maslow, 2009 [1954], 1999 [1961], 1993 [1971]; Rogers, 2005 [1961]; Elkins ir kt., 1988; Elkins, 1998, 2015) postulatai bei principai, kurių pagrindu buvo sukurtas mūsų siūlomas teorinis-empirinis humanistinio dvasingumo raiškos modelis (Kontrimienè, 2018). Jị sudaro trys komponentai: savęs aktualizavimas, transcendavimas ir gyvenimo prasmès (iš)gryninimas. Toliau pateikiame šių komponentų išsklaidą, o 2-oje lentelëje pristatomos šių komponentų apraiškos, jas išskleidžiantys rodikliai ir jų raiškos empiriniai požymiai.

\subsection{Pirmasis Humanistinio dvasingumo modelio komponentas: savęs aktualizavimas}

Savęs aktualizavimo terminas vartojamas įvairiose psichologijos teorijose, nors šio reiškinio sampratos dažnai šiek tiek skiriasi. Ši terminą sukūrẻ vokiečių neurologas ir psichiatras K. Goldstein'as, jị apibrėžęs kaip asmens motyvaciją realizuoti savo potencialą. K. Goldstein'o (1995 [1934]) teigimu, savęs aktualizavimas yra aukščiausias ir vienintelis tikras organizmo motyvas, tendencija aktualizuoti, kiek tai įmanu, individualius organizmo gebejimus; tai pagrindinè vara, kuri lemia organizmo gyvenimo kryptis.

Nemaža dalis to, ką talpina šis apibūdinimas, sutampa su A. Maslow'o išsakytomis mintimis apie savęs aktualizavimą: A. Maslow'as (2009 [1954]) teigè, kad aktualizuoti save reiškia patenkinti poreikị būti geram, jaustis visiškai gyvu ir kartu taikoje su savimi bei atrasti tikrą gyvenimo prasmę. Kitaip nei trūkumo poreikiai, kurie gali būti patenkinti, savęs aktualizavimo poreikis, dar vadinamas Būties arba augimo poreikiu, yra neišsenkantis motyvuotojas, arba elgesio skatulys ${ }^{1}$.

Siekdamas atrinkti saviaktualizacijos analizei tinkamus asmenis, A. Maslow'as ištyrẻ kelis tūkstančius asmenų ir nustatè, kad save aktualizavę tèra vos 1-2 proc. Jo teigimu, tokie žmonès ,pasirode ir nepaprastai dvasingi, ir itin pagoniški bei jusliški““ (Maslow, 2009, p. 218). Todèl galima neabejoti tuo, kad dvasingumas ne-

1 I. Ivtzan'o ir jo kolegų (2013) teigimu, savęs aktualizavimu mėgaujamasi savaime, šis procesas suteikia vidinị atlygị ir jo nesiekiama tam, kad palengvètų, kaip būna siekiant patenkinti žemesnius poreikius. 
atskiriamas nuo savęs aktualizavimo, nors pats A. Maslow'as teigè (1991), kad tai nèra aukščiausias žmogaus vystymosi etapas: šis kelias driekiasi dar aukščiau transcendavimą, ir tik šios viršūnès aukštumose žmogui iki galo atsiveria bekraščiai teisingo žinojimo bei aukščiausios dvasinès būties, kartu ir gyvenimo prasmès horizontai.

Savęs aktualizavimas A. Maslow’o teorijoje (2009, p. 189-219) apima penkiolika esminių tendencijų, jos yra:

1. Efektyvesnis tikrovès suvokimas ir labiau patenkinami santykiai su ja.

2. Savęs, kitų ir gamtos pripažinimas.

3. Spontaniškumas, paprastumas, natūralumas.

4. Išorinio pasaulio problemoms teikiama svarba.

5. Atsiskyrimas; privatumo poreikis.

6. Autonomija; nepriklausomybè nuo kultūros ir aplinkos; valia; aktyvūs veikèjai.

7. Naujas žvilgsnis ị tikrovę.

8. Mistinè patirtis: viršūnių išgyvenimai.

9. [Vok.] Gemeinschaftsgefühl (bendrystės jausmas).

10. Tarpasmeniniai santykiai.

11. Demokratinè charakterio struktūra.

12. Tikslų ir priemonių, gèrio ir blogio skyrimas.

13. Filosofiškas, neagresyvus humoro jausmas.

14. Kūrybingumas.

15. Pasipriešinimas kultūros poveikiui; kultūros transcendentiškumas.

Apibendrinant save aktualizuojančių asmenų savybes, juos galima apibūdinti šiais būdvardžiais: motyvuotas, įsijautęs, konstruktyviai mąstantis, lakios vaizduotès, negynybiškas, pasitikintis, turtingas ir laisvas vidumi, atsakingas, demokratiškas, tolerantiškas, priimantis, toks, kuriam rūpi, kuklus, integralus, sèkmingas, laimingas. A. Maslow'as (2009) teigè, kad save aktualizuojantys žmonės ịveikia dichotomijas, jiems išnyksta poliariškumai, daugelis priešybių susilieja, sudarydamos vienovę. Taigi šimtmečius egzistavusios širdies ir smegenų, proto ir instinkto, pažinimo ir troškimo priešybès sveikiems, kitaip - save aktualizuojantiems žmonėms išnyksta, užuot buvusios antagonistinès, jos virsta sinerginėmis.

Tolesnèje analizèje, remdamiesi savęs aktualizavimo reiškinio sampratą tyrinejjusių autorių (Shostrom, Knapp, 1976; Sumerlin, Bundrick, 1996; Leclerc ir kt., 1999; Ivtzan ir kt., 2013) idejjomis ir mūsų pačių atlikta šio reiškinio analize, išskyrème keturias pagrindines savęs aktualizavimo apraiškas, kurios apima A. Maslow'o $(2009 ; 1993)$ aprašytas tendencijas, kitaip - rodiklius ir jų empirinius požymius (žr. 2 lentelę). 


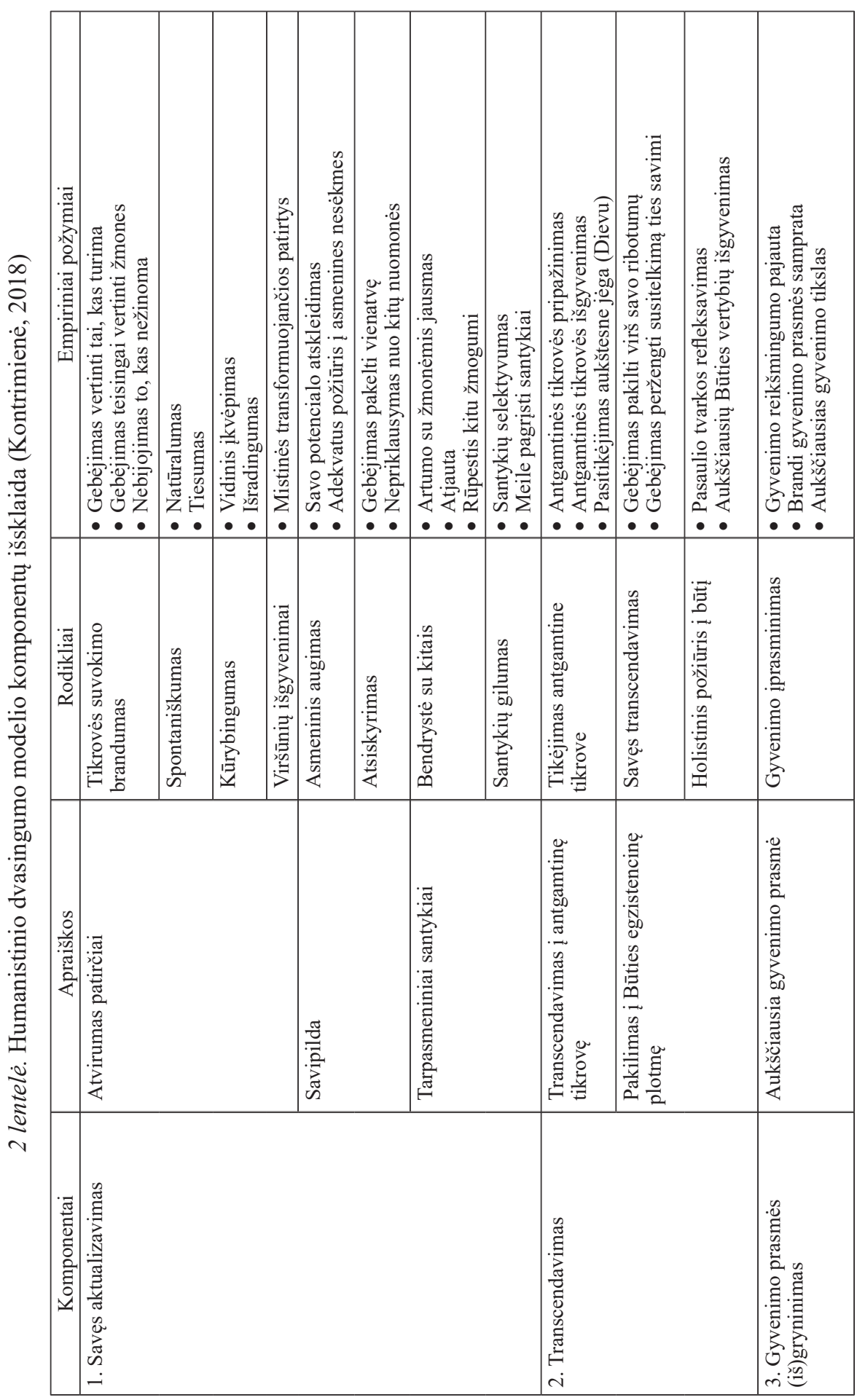


2.2. Antrasis Humanistinio dvasingumo modelio komponentas transcendavimas

Transcendavimas, kaip viena iš dvasingumo dimensijų, gali reikštis asmens religingumu ir kitomis tikèjimo aukštesniaja jèga bei harmoninga gyvenimo tvarka sklaidos formomis. A. Maslow'o teorijoje transcendavimas yra „holistinis kosmoso, kaip vienovès, suvokimas“" (1993, p. 263), kai viena kitą paneigiančių priešybių skirtumai susilieja ị darnią visumą, iš Trūkumo plotmès pereinama ị Būties plotmę, su meile priimant ir apkabinant savo lemtị tampama „panašiu ị Dievą“ (p. 264) visažiniu, visagaliu ir pakylama virš to, kas viso labo žmogiška. Žmogus tampa metažmogumi, arba Būties žmogumi, - šis gebèjimas galimai slypi jo prigimtyje.

A. Maslow'as (1993) transcendavimo sąvoką vartojo kaip dvasingumo ir aksiologijos sinonimą ir teigè, kad transcendavimas yra savęs aktualizavimo tąsa, nes savęs aktualizavimas yra būtinas, bet ne paskutinis žingsnis asmens, kurị A. Maslow'as vadina „transcenduojančiu save aktualizuojančiu žmogumi““(1993, p. 260), tapsme. Transcendavimas nusako ir motyvacinę būseną, kurios apimtas individas siekia peržengti asmeninę naudą ir yra aukštesnès misijos įgyvendinimo, sąlajos su aukštesniaja jèga ir/ar tarnystès kitiems, kaip tapatumo virš asmeninio egocentrizmo, išraiška, o šią nusako nebesiekimas, nebenorejjimas ir nebesikišimas tradiciškai suprantama prasme, kai jaučiamasi atvykus, o ne trokštama patekti, kai mylima ir priimama visa ir visi, kai susitaikoma su skaudinančiu blogiu ir kai nebegali prilipti joks purvas.

Humanistinio dvasingumo sampratą plètojantys D. Elkins'as ir jo kolegos (Elkins ir kt., 1988; Elkins, 2015) teigia, kad transcendavimo turinys gali varijuoti nuo tradicinio tikèjimo asmeniniu Dievu iki psichologinio požiūrio, kad transcendavimas yra natūrali sąmoningo Aš tąsa ị pasąmonès, arba Aukštesnijịi, Aš. Koks turinys, tipologijos, metaforos ar modeliai bebūtų pasitelkiami apibūdinant transcendavimo komponentą, ji patiriantis žmogus tiki, kad yra kažkas daugiau - kad tai, kas „matoma“, dar ne viskas.

Psichologas R. Piedmont'as (2001) transcendavimą tapatina su dvasingumu, skiria septynis jo komponentus (žr. 1 lentelę) ir apibūdina jị kaip hierarchiškai organizuotą psichologinio funkcionavimo domeną pridurdamas, kad transcendavimo lygmuo yra asmens santykio su nematoma realybe ir iš jos gaunamos emocinès paramos rodiklis.

Filosofas M. Westphal'as teigia, kad transcendavimas būtinai turi būti tyrinèjamas ,santykyje su žmogaus savęs transcendavimu“ (2004, p. 230). Savęs transcendavimas suprantamas kaip , judesys, atitraukiantis mus nuo natūralaus susitelkimo ị save“ (Westphal, 2004, p. 2), gebejjimas ,pakilti virš“ ankstesnès savo formos ar būsenos, taip fiziškai ar mentaliai peržengiant savo ribotumus. Galima sakyti, kad 
transcenduodamas save asmuo pakyla virš savo poreikių ir susitelkia ties tarnyste kitiems ar kitkam (Otway, Carnelley, 2013): tokia tarnyste papildo savęs aktualizavimo lygmeniui būdingą tarnystę sau, arba asmeninio tobulèjimo siekị. Viso to pasiekti padeda gili kontempliacija, refleksija, meditacija ir/ar malda, kurios atveria ir išgrynina giliausias žmogiškosios egzistencijos tiesas, leidžia per savęs transcendavimą pakilti ị transcendavimą į Dievą, kitaip - į aukštesnę jègą, ir patirti gyvenimą keičiančią vienovę su ja. Visa tai patiriama ir per A. Maslow'o išskirtus viršūnių išgyvenimus, sudarančius kiekvienos religijos šerdi - intensyvios ramybės ir džiaugsmo patirtis, pilnatvès akimirkas, kai atrodo, kad gyvenimas igyja naują prasmę, visa tai priimant kaip ,iš kitur“ atejjusią dovaną (žr. Maslow, 1993; 2009).

Apibendrinant galima teigti, kad dvasinis transcendavimas atskleidžia asmens gebẻjimą peržengti momentinę laiko, vietos ir žinojimo ribų pajautą bei pažvelgti i gyvenimą iš platesnès perspektyvos. Išlavintą transcendavimo gebẻjimą turintys žmonès tiki, kad egzistuoja aukštesnis gyvenimo planas ar prasmè, tai, kas yra anapus mūsų mirtingos egzistencijos, kitaip - antgamtišku apreiškimu besiremiantis „didysis naratyvas“. Modelyje skiriamos dvi transcendavimo apraiškos, jų rodikliai ir empiriniai požymiai (žr. 2 lentelę).

2.3. Trečiasis Humanistinio dvasingumo modelio komponentas:

gyvenimo prasmès (iš)gryninimas

Asmens gyvenimo prasmès samprata didele dalimi lemia tai, kaip jis aiškina svarbiausius gyvenimo klausimus ir ribines gyvenimo situacijas - gyvenimo ir mirties prigimtị, kančios ir skausmo prasmingumą, tai, kas iš tiesų svarbu. Akivaizdu, kad gyvenimo prasmès sampratos ir apibrèžtys gali gerokai skirtis, mokslinèje literatūroje jos varijuoja nuo ,gyvenimui suteikiamos darnos“, „gyvenimo kryptingumo ir tikslingumo“ “iki „ontologinio gyvenimo reikšmingumo“ (Steger ir kt., 2006, p. 80).

Humanistinès žmogaus laisvès, tobulumo ir racionalaus proto svarbą pabrèžiančios idèjos kildinamos iš I. Kant'o (2011 [1785]; 1998 [1781]) filosofijos, pagal kurią kategorinis imperatyvas taikytinas visiems laisvos valios gebantiems mąstyti žmonèms, todèl šioje prieigoje pagrịstai galima išskirti universalia gyvenimo prasmès sampratą, suvokiant, kad gyvenimo prasmė egzistuoja esmiškai, objektyviai ir yra neatskiriamai susijusi su aukščiausiomis dvasinėmis vertybėmis, kurios nušviečia tinkamiausią gyvenimo kelio kryptị. Pasak filosofo M. Scheler'io (1973 [1913]), vertybès, kurias žmogus jaučia ir išgyvena todèl, kad turi vertybių juslę, susijusios tam tikra tvarka ir sudaro hierarchiją, aukščiausios čia yra religi- 
nès vertybès, atskleidžiančios aukščiausią šventumo būvị numinosum ${ }^{2}$. Šios aukščiausio modalumo vertybės yra absoliučios, jos skiriasi nuo visų kitų, nes gali būti suvokiamos tik ypatingais vertybiniais pažintiniais dvasios aktais.

Kitaip tariant, gyvenimo prasmès brandumas ir tvarumas priklauso nuo to, kiek žmoguje skleidžiasi patirties šventumas, o ši galima apibrěžti skirtingai (žr.Elkins, 1998), teologas R. Otto (1961 [1923]) tai vadinojausminiu tikinčiojo atsa$\mathrm{ku}$ - dieviškos galios mysterium tremendum et fascinans patyrimu; religijos istorikas M. Eliade (1961) šventumo dimensijai nusakyti vartojo hierofanijos, arba šventybės apsireiškimo, terminą, kuris nusako tai, kas tikrai tikra, o ne tai, kas sekuliaru, taigi netikra arba pseudotikra, kai padaromas galas santykinumui, sąmyšiui ir kažkas, nepriklausantis šiam pasauliui, ịsakmiai apsireiškia bei nurodo tam tikrą kryptį; M. Buber'is (1970) tokias patirtis vadino šventumo kupinu Aš-Tu santykiu, kuriame Tu gali būti ne tik žmogus, bet ir Dievas, ir kuriame dèl gautos malonès ir amžinybès ịsiliejimo ị laiką patiriama tai, kas šventa, nepamirštama, kas visam laikui keičia gyvenimą ir supratimą; A. Maslow'as (1994) patirties šventumą siejo su viršūnių išgyvenimais, nukeliančiais žmogų i Būties karalystę, kurioje siela atsiveria ir jis ima matyti kasdienybę, artimą ir tolimą šventumo šviesoje, jam atsiveria transcendentinė realybė, aplanko gili Būties vertybių pajauta; D. Elkins'as (1998) šventumą ịvardija kaip galingą gyvenimo dimensiją, kuri reiškiasi per skvarbius gyvenimo momentus, jau minètas viršūnių patirtis arba mistinius susidūrimus: jeigu tokios šventos patirtys nuolat maitina žmogaus sielą, jis neišvengiamai auga dvasiškai.

Tačiau tam, kad tai patirtų, žmogus turi pasiekti ,šventos sąmonès“ būseną, kaip ją vadina D. Elkins'as (1998), kuriai apėmus galima jausti, patirti ir žinoti visa, kas neprieinama esant „normalios“, arba „sekuliarios“, sąmonès būsenos. Ši būsena leidžia panirti ị tai, ką galima įvairiai vadinti: antgamtiškumu, Būties dimensija, psichikos gelmèmis, aukštesniaja savastimi, kolektyvine pasąmone, tolimesniais žmogaus prigimties horizontais, šventumu ar dvasine plotme. Išgrynintas gyvenimo prasmès suvokimas padeda žmogui kurti brandesnius santykius su Kitais ir matyti gilią prasmę juose: dvasinės brandos formuojama gyvenimo prasmès pajauta tarsi nuspalvina kiekvieną gyvenimo įvykị ir užtikrina tam tikrą apsaugą, kuri leidžia nukritus vél pakilti, atsitiesti.

2 Teologas ir filosofas Rodolph'as Otto (1961 [1923]) numinosum pavadino religini fenomeną, kuris gali būti verčiamas žodžiu šventybè. Tai niekio patirtis, kuri reiškiasi per du prigimtinius jausmus - tremendum ir momentum fascinans. Tremendum - tai tokia nesuvokiama realybė, kurios ištiktą žmogų apima begalinis siaubas nesuvokiamo niekio, esančio begaline galia, akivaizdoje. Kartu su šiuo siaubą keliančiu jausmu atsiranda ekstatiškas pasigèrèjimo, žavesio ta begaline galia jausmas, kuris kartais būna toks stiprus, kad aptemsta sąmonè. Tai yra momentum fascinans. Ji kelia ne tik pagarbią baimę ar net siaubą, bet ir susižavejjimo kupiną nuolankumą, troškimą be atodairos mylèti ir garbinti (Kanišauskas, 2014). 
Taigi išgrynintos gyvenimo prasmès samprata implikuoja tikèjimą aukštesniaja jèga ir patirties šventumą, padedančius žmogui siekti harmonijos, brandžių santykių su pasauliu ir suprasti, kaip pasaulis reflektuoja jo sąmoneje. Gyvenimo prasmės išgryninimas (modelyje išskiriama viena jo apraiška, jos rodikliai ir jų empiriniai požymiai (žr. 2 lentelę)) suteikia gilesnị žinojimą, multifokalų žvilgsni, aprépiantị visas žmogaus gyvenimo dimensijas, o tai yra būtina, siekiant teisingai surikiuoti mintis ir gyvenimo įvykius. Iš viso to išplaukia mūsų siūlomas humanistinio dvasingumo apibrèžimas: dvasingumas - tai asmens savęs aktualizavimo ir transcendavimo patirčiu suteikiamu prasmiu išgryninimas, igalinantis sveika santykị su savimi, kitais, aukštesne realybe ir pasauliu.

\section{Humanistinio dvasingumo aprašo validavimo tyrimas}

Ankstesneje straipsnio dalyje pristatyto Humanistinio dvasingumo modelio pagrindu sukurtas mūsų siūlomas dvasingumo matas - Humanistinio dvasingumo aprašas (galutinis aprašo variantas pateiktas 3 lentelejje). Siekiant užtikrinti aprašo turinio validumą, pirminị aprašo variantą vertino keturi ekspertai: dvi dvasingumą tiriančios ir jo sampratą plètojančios Lietuvos mokslininkès bei dvasinėmis praktikomis užsiimantys profesionalus jogos mokytojas ir katalikų vienuolis. İ ekspertų ¡ž̌valgas ir pastabas atsižvelgta kuriant naujus ir koreguojant jau sukurtus teiginius, o tai, kad ekspertai sutare dèl daugiau nei 90 proc. pirminį aprašo variantą sudariusių teiginių tinkamumo, rodo aukštą instrumento turinio validumą.

Aprašą sudaro trys modelio komponentus atitinkančios skalès: Savęs aktualizavimas, Transcendavimas ir Gyvenimo prasmès (iš)gryninimas, kurių teiginiai matuoja modelyje išskirtų rodiklių raišką per jų empirinius požymius. Pirminiame aprašo variante iš viso buvo 56 teiginiai: 34 - matuojantys savęs aktualizavimą (pvz.: „Tikiu, kad manęs nepalaužtų net ir didžiausi gyvenimo smūgiai“; „Galiu pasakyti, kad jaučiu artumą visiems žmonėms"); 14 - matuojantys transcendavimą (pvz.: „Dažnai patiriu jausmą, kai peržengiu save ir man atsiveria kur kas gilesni realybės aspektai“; „Dažnai pasineriu ị gilias refleksijos būsenas, medituoju ir/ar meldžiuosi“") ir 8 - matuojantys gyvenimo prasmès (iš)gryninimą (pvz.: „Mano gyvenimo prasmè neatsiejama nuo tikèjimo aukštesne jèga ir meilès“; „Tikèjimas padeda man įžvelgti prasmingus ryšius tarp įvykių, kurie nèra tiesiogiai susiję"). Teiginiai vertinami pagal Likert’o skalę nuo 1 (visiškai nesutinku) iki 7 (visiškai sutinku), vidurinis rangas žymi atsakymą nei sutinku, nei nesutinku. Pristatomu aprašo validavimo tyrimu tikrintos kitos psichometrinès aprašo savybės.

Statistiniam tyrimo duomenu apdorojimui naudotas programinis paketas SPSS21.0. Skaičiuoti bendri (išvestiniai) ịverčiai, vidurkiai, standartiniai nuokrypiai, patikimumo (instrumento teiginių vidinio suderintumo) koeficientai 
(Cronbach'o $\alpha$ ), tikrinamas skirstinių normalumas (Kolmogorov'o-Smirnov'o testas), atliekama faktorių analizè, skaičiuojamos koreliacijos (Pearson'o ir Spearman'o koreliacijos koeficientai). Rezultatai vertinti kaip statistiškai reikšmingi, kai reikšmingumo lygmuo $p<0,05$.

Tyrimo dalyviai. Aprašo validavimo tyrime dalyvavo 331 asmuo: 137 (41\%) vyrai ir 194 (59\%) moterys, kurių amžius - 18-71 metai, vidurkis - 31,2 m. (st. nuokr. - 14,2). 165 dalyviai buvo Vilniaus universiteto įvairių studijų programų (psichologijos, socialinès politikos, moderniujų technologijų fizikos ir vadybos, ekonometrijos bei informatikos) pirmosios studijų pakopos studentai, atrinkti taikant patogiosios atrankos metodus; kiti 166 dalyviai - vyresnio amžiaus, atrinkti taikant tikslinès ir "sniego gniūžtès“ atrankos metodus. Daugumos, t. y. 134-ių (arba 40,5 \% visos imties), dalyvių išsilavinimas - aukštasis, 21-o (6,3 \%) - aukštesnysis, 6-ių (1,8 \%) - spec. vidurinis, 4-ių (1,2\%) - nebaigtas aukštasis.

\subsection{Pirminio Humanistinio dvasingumo aprašo varianto patikimumas}

\section{Vidinio suderintumo patikimumas}

Pirmame analizės etape tikrintas pirminio aprašo varianto teiginių vidinio suderintumo patikimumas: apskaičiuotos Cronbach'o alfa koeficiento reikšmės visoms trims skalëms. Gautos šios reikšmès: $\alpha=0,88$ visam Humanistinio dvasingumo aprašui, $\alpha=0,73$ - Savęs aktualizavimo, $\alpha=0,83$ - Transcendavimo ir $\alpha=0,80$ - Gyvenimo prasmès (iš)gryninimo skalèms. Visų koeficientų reikšmès viršija 0,7 , todèl galima teigti, kad pirminio Humanistinio dvasingumo aprašo varianto teiginių vidinio suderintumo patikimumas yra pakankamai aukštas. Vis dèlto iš Savęs aktualizavimo ir Transcendavimo skalių buvo nuspręsta pašalinti du teiginius, nes jie gerokai mažino šių skalių patikimumą (nurodytos koeficientų reikšmès apskaičiuotos iki šių teiginių pašalinimo). Kadangi tolesniuose analizès etapuose buvo pašalinta dar daugiau teiginių, baigiant validuoti aprašą teiginių vidinio suderintumo patikimumas buvo apskaičiuotas iš naujo.

\section{Pakartotinio testavimo patikimumas}

Vèlesniame analizès etape tikrintas šio aprašo varianto pakartotinio testavimo patikimumas. Dalis dalyvių $(N=109)$, pildžiusių aprašą pirmą kartą, užpilde jị dar kartą praejus dviem savaitėms po pirmojo pildymo. Gautos šios koreliacijų tarp aprašo skalių ịverčių, gautų po pirmo ir antro instrumento pildymų, koeficientų reikšmès: 0,91 - Humanistinio dvasingumo aprašo (HDA); 0,856 - Savęs aktualizavimo; 0,909 - Transcendavimo ir 0,880 - Gyvenimo prasmės (iš)gryninimo. Visos šios reikšmès yra aukštos, todèl galima daryti išvadą, kad pirminis Huma- 
nistinio dvasingumo aprašo variantas pasižymi aukštu pakartotinio testavimo patikimumu.

\subsection{Humanistinio dvasingumo aprašo konstruktų validumas}

\section{Validumas, remiantis faktoriu analize}

Tikrinant aprašo skalių konstruktų validumą, pirmiausia atlikta patvirtinamoji faktorių analizė su Varimax sukimu, kuria siekta nustatyti, ar aprašo teiginiai, remiantis tyrimo imties rezultatais, gali būti priskiriami prie tų skalių, kurių sudètyje jie yra paisant modelio logikos. Analizè atskleide, kad trys HDA faktoriai paaiškina 37 proc. kintamujų reikšmių dispersijos $(\mathrm{KMO}=0,872$, Bartlett'o kriterijaus $p=0,000)$.

I pirmaji faktorių susivede 10 iš pirminių 14-os Transcendavimo skalès teiginių, kuriems šio faktoriaus svoris viršijo 0,4 , tačiau vieną anksčiau minètą teigini nuspręsta iš aprašo šalinti, nes jis gerokai mažino skalès patikimumo koeficientą, todèl šioje skalèje liko 9 teiginiai (žr. 3 lentelę).

3 lentelè. Humanistinio dvasingumo aprašas (Kontrimienè, 2018)

Instrukcijos. Kiekvienam teiginiui ịrašykite skaičių pagal septynių balų skalę (nuo 1 = visiškai nesutinku iki 7 = visiškai sutinku), kuris geriausiai apibūdina, kiek teiginys tinka jums. Rinkites tuos atsakymų variantus, kurie iš tiesų apibūdina jūsų patirtị, o ne žymi tai, kaip jums atrodo, kad turètų būti. Čia nėra teisingų ar neteisingų atsakymų, todèl atsakinèkite ilgai negalvodami. Svarbu, kad nepraleistumėte nė vieno teiginio.

\begin{tabular}{|c|c|c|c|c|c|c|}
\hline $\mathbf{1}$ & $\mathbf{2}$ & $\mathbf{3}$ & $\mathbf{4}$ & $\mathbf{5}$ & $\mathbf{6}$ & $\mathbf{7}$ \\
$\begin{array}{c}\text { Visiškai } \\
\text { nesutinku }\end{array}$ & Nesutinku & $\begin{array}{c}\text { Siek tiek } \\
\text { nesutinku }\end{array}$ & $\begin{array}{c}\text { Nei taip, } \\
\text { nei ne }\end{array}$ & $\begin{array}{c}\text { Šiek tiek } \\
\text { sutinku }\end{array}$ & $\begin{array}{c}\text { Sutinku } \\
\text { Visiškai } \\
\text { sutinku }\end{array}$ \\
\hline
\end{tabular}

1. Dažnai susimąstau apie tai, kad viskas gyvenime vyksta pagal harmoningą tvarką (Tr)

2. ___ Jaučiu, kad gyvenimas yra besąlygiškai reikšmingas (GPI)

3. N__ Nežinomybè mane veikiau gąsdina, o ne traukia (SA) atr3

4. ___ Galiu pasakyti, kad esu išradinga(-s), pvz., kai reikia, lengvai surandu originalius sprendimus (SA)

5. ___ Man dažnai būna sunku elgtis natūraliai, nes kiti gali to nepriimti (SA) $)^{\text {atv }}$

6. ___ Noras būti tiesiam leidžia pateisinti netaktą (SA)

7. Tikiu, kad net ir tamsiausioje patirtyje slypi prasmè (GPI)

3 Teiginys vertinamas atvirkščia kryptimi. 
8. Mano gyvenimo prasmè neatsiejama nuo tikejjimo aukštesne jèga ir meilès (GPI)

9. ___ Mano gyvenimą labiau ịprasmina noras siekti asmeninio augimo ir artimuju gerovès, o ne dvasinio tobulejjimo (GPI) ${ }^{\text {atv }}$

10. ___ Dažnai pasineriu ị gilias refleksijos būsenas, medituoju ir/ar meldžiuosi (Tr)

11. Kartais patiriu akimirkas, kai apima gili ramybè, pilnatvè, ekstazè, tarsi savojo ,ašc praradimas (SA)

12. __ Man dar nepavyksta pakilti virš savo egocentrizmo, ambicijų, savigraužos $(\operatorname{Tr})^{\text {atv }}$

13. ___ Dažnai jaučiu, kad turiu daryti tai, ko iš manęs tikisi kiti (SA) atv

14. ___ Išgyvenu labai artimus santykius su žmonėmis, kurių vertybès tokios pat kaip mano (SA)

15. ___ Negalèčiau tvirtinti, kad man labai patinka mano darbas (studijos) (SA) atv $^{\text {atv }}$

16. ___ Ateis laikas, kai pradėsiu gyventi iš tikrujų, ne taip, kaip dabar (SA) atv

17. Žmonių silpnybès pastebimos daug labiau nei stiprybès (SA)

18. __ Nebijau išsiskirti iš kitų, kai reikia ginti tiesą (SA)

19. Tikiu, kad manęs nepalaužtų net ir didžiausi gyvenimo smūgiai (SA)

20. ___ Galiu pasakyti, kad mano santykị su kitais žmonėmis ir visu pasauliu ịkvepia mano tikèjimas aukštesne jèga (Tr)

21. ___ Dažnai jaučiu ryšį su aukštesne jèga (Dievu) (Tr)

22. ___ Tikiu, kad aukštesnè jèga (Dievas) visada suteiks man stiprybès (Tr)

23. ___ Nemanau, kad egzistuoja kažkokia aukštesnè realybè - aš tiesiog gimiau ir mirsiu (Tr) $)^{\text {atv }}$

24. ___ Mane liūdina tai, kad didžioji mano gyvenimo dalis praeina tuščiai $(\mathrm{SA})^{\text {atv }}$

25. ___ Man sunku susitaikyti su tuo, kiek išbandymų man siunčia gyvenimas (SA) ${ }^{\text {atv }}$

26. ___ Tikèjimas man padeda ịžvelgti prasmingus ryšius tarp ịvykių, kurie nèra tiesiogiai susiję (GPI)

27. Kartais patiriu akimirkų, kai apima nuostabos ir baimingos pagarbos jausmas, kai jaučiuosi tarsi pakilęs(-usi) ị aukštesnị būties lygmenị (SA)

28. ___ Meditacija, malda ir/ar refleksija man padeda išgyventi aukščiausias vertybes tiesą, gèri ir groži (Tr)

29. ___ Dažnai patiriu jausmą, kai peržengiu save ir man atsiveria kur kas gilesni realybès aspektai $(\mathrm{Tr})$

30. ___ Galiu pasakyti, kad jaučiu artumą visiems žmonèms (SA)

31. Esu jautrus(-i) kitų išgyvenimams (SA)

32. Man sunku ištverti vienatvę (SA) ${ }^{\text {atv }}$

33. Sugebu mylèti net ir tada, kai nesulaukiu atsako (SA)

34. Gyvenime mes neišvengiamai dèvime kaukes (SA) atv

35. ___ Nemanau, kad padèti kitiems yra mano pareiga (SA) atv

36. N__ Negalèčiau apibendrintai pasakyti, koks mano gyvenimo tikslas - jis priklauso nuo gyvenimo situacijos (GPI) atv

37. ___ Nesistengiu ịžvelgti gilesnès prasmès ịvykiuose, kurie man atrodo atsitiktiniai $(\mathrm{GPI})^{\mathrm{atv}}$ 
38. _ _ Bet kuri darbą darau su vidiniu užsidegimu (SA)

39. ___ Žinau, kad gyvenime nuveiksiu kažką svarbaus ir ypatingo (SA)

40. S__ Savo gyvenimo tikslą labiau sieju su dvasiniu augimu nei su materialios gerovès, pripažinimo ar netgi šeiminès laimès siekiu (GPI)

Dera pastebèti, kad šio faktoriaus svoriai buvo didžiausi dar trims ne šiai, o kitoms (Savęs aktualizavimo ir Gyvenimo prasmès (iš)gryninimo) skalèms priklausantiems teiginiams, tačiau siekiant nenukrypti nuo Humanistinio dvasingumo modelio struktūros, šiuos teiginius nuspręsta išlaikyti pirminėse skalèse, juolab kad pagal faktorių svorius $(0,495$ vs 0,$410 ; 0,527$ vs 0,$452 ; 0,781$ vs 0,601$)$ jie gali būti priskiriami ir prie jų.

I antrajị, Savęs aktualizavimo, faktorių susivedè ne 34 (tiek teiginių pirminiame aprašo variante sudarè Savęs aktualizavimo skalę), o 24 teiginiai, kuriems faktoriaus svoris viršijo 0,390 reikšmę. Kitiems dešimčiai teiginių ne tik šio, bet ir kitų faktorių svoriai buvo mažesni nei 0,390, todẻl nuspręsta juos iš aprašo šalinti. Galiausiai (kaip minėta) vienam teiginiui šio faktoriaus svoris buvo mažesnis nei pirmojo faktoriaus, bet kadangi ir jis viršijo reikiamą 0,4 reikšmę, teigini nuspręsta palikti šioje skalëje. Be to, vieną teiginị nuspręsta šalinti iš aprašo, nes jis gerokai mažino Savęs aktualizavimo skalès patikimumo koeficientą, todèl iš viso šioje skalëje liko 23 teiginiai.

I trečiaji faktorių, kuris aiškina Gyvenimo prasmès (iš)gryninimo skalès teiginius, susivedè visi 8 šios skalès teiginiai, nes jiems visiems šio faktoriaus svoriai viršijo 0,4 (nors, kaip jau rašème, dviejų teiginių pirmojo faktoriaus svoriai buvo dar didesni greičiausiai todèl, kad teiginiais klausta, ar asmens gyvenimo prasmè susijusi su tikèjimu).

\section{Konvergentinis validumas}

Aprašo ir jo skalių konvergentinis validumas tikrintas apskaičiuojant jų koreliacijas su trimis kitais mokslinėje literatūroje pripažintais tuos pačius konstruktus (savęs aktualizavimą, transcendavimą ir gyvenimo prasmę) matuojančiais instrumentais.

Savęs aktualizavimas. Siekiant nustatyti, ar HDA Savęs aktualizavimo skale pasižymi pakankamu konvergentiniu validumu, tyrime naudotas Trumpasis savęs aktualizavimo indeksas (angl. Short Index of Self-Actualisation; Jones, Crandall, 1986). Instrumentą sudaro 15-a teiginių, pvz.: ,,Tikiu, kad apskritai žmonès yra geri ir jais galima pasitikèti.“ Teiginiai vertinami pagal Likert'o skalę nuo 1 (visiškai nesutinku) iki 6 (visiškai sutinku), kuo ịvertis aukštesnis, tuo asmuo labiau save aktualizuoja.

Transcendavimas. Tam, kad būtų nustatyta, ar tinkamas ir HDA Trancendavimo skalès konvergentinis validumas, tyrime naudota Dvasinio transcendavimo 
skale (angl. Spiritual Transcendence Scale; Piedmont, 1999), kurią sudaro 24 teiginiai, sudarantys tris subskales: Pilnatvé maldoje (angl. Prayer Fulfillment), pvz., „kai meldžiuosi ar medituoju, atsiriboju nuo šio pasaulio įvykių“, Universalumas (angl. Universality), pvz., „tikiu, kad egzistuoja aukštesnè gyvenimo prasmë“ ir Susietumas (angl. Connectedness), pvz., „esu savo šeimos paveldo grandis, tiltas tarp praeities ir ateities". Kiekvieną skalę sudaro 8 teiginiai, kurie vertinami pagal Likert'o skalę nuo 1 (visiškai nesutinku) iki 5 (visiškai sutinku).

Gyvenimo prasmè. Tiriant HDA Gyvenimo prasmès (iš)gryninimo skalės konvergentini validumą, naudotas Gyvenimo prasmès klausimynas (angl. The Meaning in Life Questionnaire; Steger ir kt., 2006). Instrumentą sudaro 10 du paskirus konstruktus - gyvenimo prasmès įžvelgimą ir jos ieškojimą - apimančių teiginių. Gyvenimo prasmès ịžvelgimo skalę (angl. Presence) sudaro 5 teiginiai, pvz., „gerai jaučiu, kas mano gyvenimą daro prasmingą“. Kiti 5 teiginiai sudaro Gyvenimo prasmès ieškojimo skalę (angl. Search), pvz., , ieškau to, kas suteikia prasmę mano gyvenimui“. Teiginiai vertinami pagal Likert'o skalę nuo 1 (visiškai nesutinku) iki 7 (visiškai sutinku), aukštesni įverčiai reiškia, kad asmuo labiau jaučiasi suradęs gyvenimo prasmę arba jos ieško. Šiame tyrime skaičiuojant koreliacijas su HDA ir jo Gyvenimo prasmès (iš)gryninimo skale buvo svarbi tik pirmoji instrumento skalè, nes HDA labiau matuojamas gyvenimo prasmès turinys, taigi jos įžvelgimas, o ne paieška.

Visų šiame tyrime naudotų instrumentų autoriai leidžia naudoti instrumentus tyrimų tikslais be atskiro sutikimo. Instrumentus iš anglų ị lietuvių kalbą išverte šio darbo autore, profesionali vertėja, kitas profesionalus vertejjas atliko visų teiginių atgalinius vertimus ị anglų kalbą, o nepriklausomas ekspertas ịvertino, kiek „atversti“ teiginiai sutampa su originaliais ir kaip vertimas turètų būti koreguojamas, kad nebūtų pakitusi originalių teiginių prasmè.

Apskaičiuotos Pearson'o ir Spearman'o koreliacijos su kitais tuos pačius konstruktus matuojančiais instrumentais atskleidè (žr. 4 lentelę), kad Humanistinio dvasingumo aprašas statistiškai reikšmingai ir vidutiniškai arba gana stipriai koreliuoja su Gyvenimo prasmès įžvelgimo skale $(r=0,487, p<0,01)$, Trumpuoju savęs aktualizavimo indeksu $(r=0,430, p<0,01)$ ir Dvasinio transcendavimo skale $(r=0,789, p<0,01)$; reikšmingos ir koreliacijos tarp paskiru HDA ir kitų instrumentų skalių, jų reikšmės varijuoja nuo 0,401 iki 0,814 ir patvirtina aprašo skalių konvergentinị validumą. Analizuojant šias koreliacijas matyti, kad silpniausia, nors ir statistiškai reikšminga, yra sąsaja tarp HDA Gyvenimo prasmės (iš) gryninimo ir MLQ Gyvenimo prasmès ịžvelgimo skalių $(r=0,401, p<0,01)$. Tai galëjo lemti skirtingas šių instrumentų teiginių turinys, nes HDA skalès teiginiais klausiama ne tik to, ar asmuo jaučiasi suradęs gyvenimo prasmę, bet ir to, ar jos turinys atskleidžia asmens tikẻjimą aukštesniąja jèga bei dvasinio tobulëjimo siekį. 


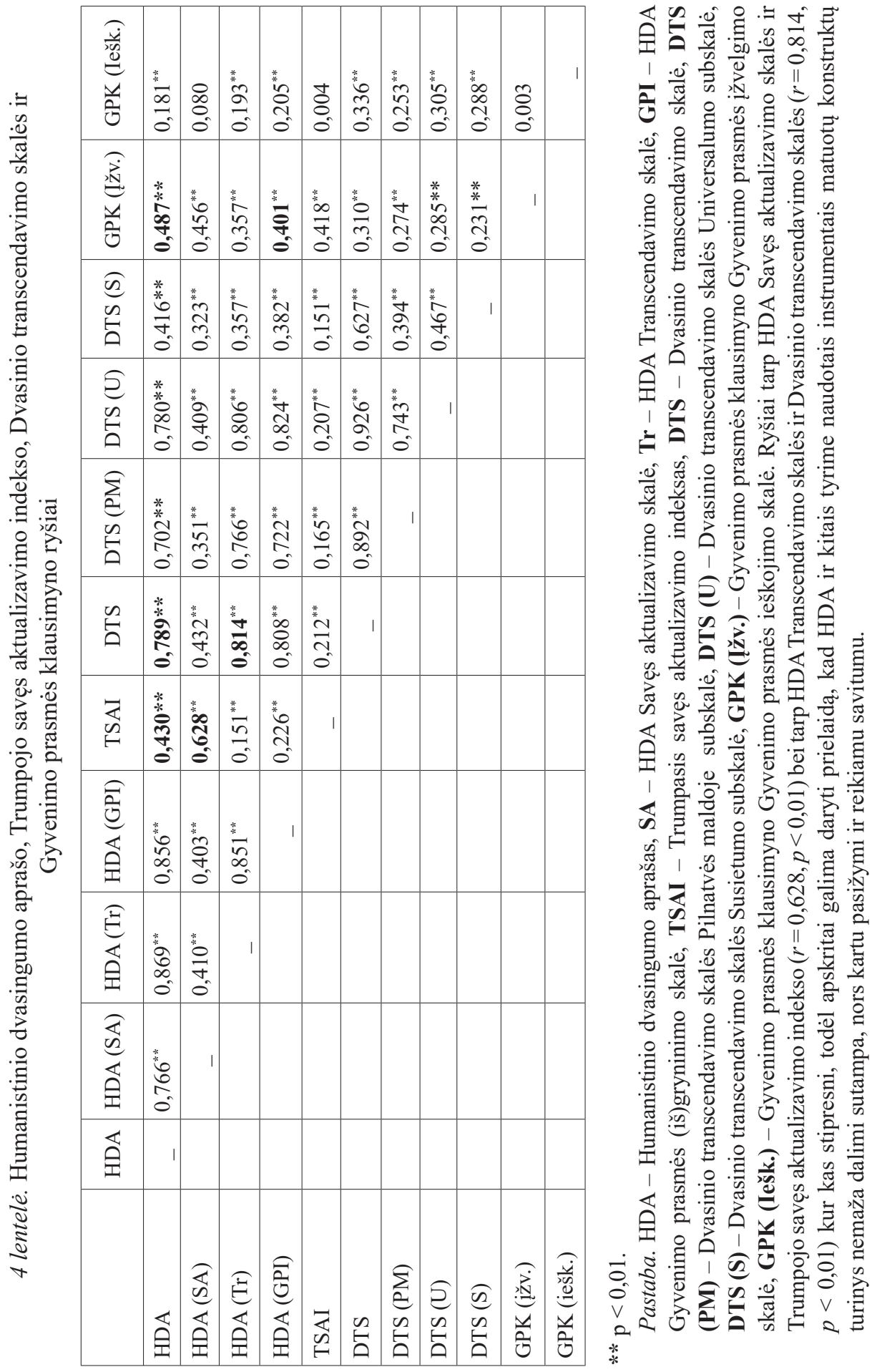




\subsection{Humanistinio dvasingumo aprašo patikimumas}

Kadangi iš viso pašalinta 16-a teiginių ir Humanistinio dvasingumo apraše liko 40 modelio logiką atitinkančių teiginių (žr. 3 lentelę), jų vidinis suderinamumas iš naujo tikrinti apskaičiavus Cronbach'o alfa koeficientus. Gautos tokios koeficientu reikšmės: 0,717 - Savęs aktualizavimo, 0,801 - Transcendavimo, 0,804 - Gyvenimo prasmès (iš)gryninimo skalèms ir 0,873 - visam Humanistinio dvasingumo aprašui. Visų koeficientų reikšmės viršija 0,7 reikšmę, todėl galima teigti, kad ir sutrumpinto Humanistinio dvasingumo aprašo teiginių vidinio suderintumo patikimumas yra pakankamai aukštas. Kadangi pasikeite galutinio aprašo varianto skalių sudètis, iš naujo patikrintas ir šių skalių pakartotinio testavimo patikimumas. Apskaičiuotos tokios koreliacijų tarp aprašo skalių ịverčių, gautų po pirmo ir antro instrumentų pildymo, koeficientų reikšmès: 0,92 - Humanistinio dvasingumo aprašo (HDA), 0,864 - Savęs aktualizavimo, 0,915 - Transcendavimo ir 0,880 - Gyvenimo prasmès (iš)gryninimo. Šios reikšmès dar aukštesnès nei pirminio aprašo varianto, todèl galima teigti, kad Humanistinio dvasingumo aprašas pasižymi aukštu pakartotinio testavimo patikimumu.

Apibendrinant atliktų HDA patikimumo ir validumo vertinimo analizių rezultatus galima daryti išvadą, kad siūlomas Humanistinio dvasingumo aprašas pasižymi tinkamomis psichometrinėmis savybėmis, todèl gali būti naudojamas kaip dvasingumo vertinimo matas dvasingumo tyrimuose.

\section{Išvados}

Dvasingumas yra sudètingas daugiamatis konstruktas, kurio turinio dèmenys gali būti skirtingai suprantami (žr. Cook, 2004; Moberg, 2002). Kartu tai gilesnès savasties negu tik fizinis, emocinis ir mentalinis kūnas atradimas, kelias ị teigiamą santykị su pasauliu, vidinę harmoniją, aukštesnę būties kokybę, per tai - ir ị gyvenimo prasmès pajautą.

Mūsų plètojama sakralaus humanistinio dvasingumo prieiga numato, kad tikrų dvasinių aspiracijų išraiška yra tikejjimo ir vidinès darnos įkvėptas gilus žmogiškos patirties ịprasminimas, kurị iggalina žmogaus tobulejjimas, žinių ir žinojimo kaupimas, o tai lemia aukščiausio tapatumo ir savasties pasiekimą, arba savęs aktualizavimą, bei natūralią jo tąsą - gebẻjimą peržengti savo ribotumą ir laiko, vietos bei žinojimo ribas atskleidžiantị transcendavimą. Straipsnyje pristatomas humanistinio dvasingumo modelis, pagal kurị dvasingumas apima savęs aktualizavimą, transcendavimą ir gyvenimo prasmès (iš)gryninimą, didele dalimi sutampa su išsamią dvasingumo modelių ir tyrimų studiją atlikusių E. de Jager Meezenbroek ir jos kolegu (2012) siūlomu dvasingumo apibrèžimu, kuriuo remiantis dvasingumo reiš- 
kinys - tai susietumo su savo savastimi, kitais, gamta ir tuo, kas transcendentiška, siekis ir patyrimas. Minètų autorių atlikta dvasingumo matų apžvalga atskleidè, kad dauguma šiuolaikinių instrumentų matuoja universalias patirtis ir nuostatas, tokias kaip susietumas, atjauta, dèkingumas, mistinès patirtys ir savęs aktualizavimas, o esminis dvasingumo, kaip universalios žmogiškos patirties, komponentas yra susietumas. Šiuos postulatus atskleidžia slaugos specialistès P. Reed (1992, p. 350) siūlomas dvasingumo apibrèžimas, kuriuo remiantis dvasingumas yra ,polinkis atrasti prasmę, pasitelkus juntamą ryšị su asmens Aš transcenduojančiomis dimensijomis, taip asmenị ịgalinant, o ne nuvertinant. Toks ryšys gali būti patiriamas vidujai (kaip ryšys savyje), tarpasmeniškai (kitų ir natūralios aplinkos kontekste) ir transpersonaliai (per juntamą ryši su tuo, kas nematoma, Dievu arba už asmens Aš didesne jèga)“. Susietumas su savo savastimi, kitais ir gamta (mūsų modelyje atitinkantis savęs aktualizavimo komponentą) reiškiasi kaip autentiškumas, vidinė harmonija, ramybė, sąmoningumas, savivoka, atjauta, rūpa, nuostaba ir gili gyvenimo prasmès pajauta (Young-Eisendrath, Miller, 2000; De Jager Meezenbroek ir kt., 2012). Susietumas su tuo, kas transcendentiška, yra ryšys su kažkuo anapus to, kas vien tik žmogiška, - Visata, transcendentine realybe, aukštesne jèga, arba Dievu. Tai reiškiasi kaip baiminga pagarba, viltis, šventumas ir transcendavimo patirtis (Cook, 2004; De Jager Meezenbroek ir kt., 2012).

Norisi tikèti, kad mūsų humanistinio dvasingumo modelis ir jo pagrindu sudarytas bei šiame tyrime validuotas Humanistinio dvasingumo aprašas atskleidžia skirtingų religinių afiliacijų asmenų patirtis ir yra tinkami šiandieninei Vakarų kultūrai, kurioje dauguma žmonių vis dažniau atranda sąlytị su dieviškumu savyje ir gyvenimo prasmę išgrynina per savas dvasingas patirtis, o ne per jiems iš išorès padiktuotas dogmas ir taisykles. Modelis ir aprašas implikuoja tai, kad savęs aktualizavimo ir transcendavimo patirčių fone suformuota brandi tikèjimo ịkvejpta gyvenimo prasmès samprata suteikia gilų visa ko supratimą ir atveria žmogui aukščiausios dvasinės būties horizontus, sudarydama sąlygas siekti darnos ir brandžių santykių su savimi, Kitu bei pasauliu.

\section{Literatūra}

Aramavičiūtè, V. (2005). Auklëjimas ir dvasinè asmenybès branda. Vilnius: Gimtasis žodis.

Aramavičiūtė, V. (2010). Vyresniųjų mokinių dvasingumas globalizacijos iššūkių kontekste. Lietuvių kataliku mokslu akademijos metraštis, Nr. 33, p. 193-211.

Belsky, J. (1997). Attachment, mating, and parenting - an evolutionary perspective. Human Nature, Vol. 8, p. 361-381. Bitinas, B. (2004). Hodegetika: auklejimo teorija ir technologija. Vilnius: Kronta.

Buber, M. (1970). I and Thou. New York: Charles Scribner's Sons.

Cook, C. C. H. (2004). Addiction and spirituality. Addiction, Vol. 99, p. 539-551.

Corrington, J. E. (1989). Spirituality and recovery: Relationships between levels of spirituality, contentment, and stress during recovery form alcoholism in AA. Alcoholism Treatment Quarterly, Vol. 6, p. 151-165.

De Jager Meezenbroek, E., Garssen, B., van den Berg, M., van Dierendonck, D., Visser, A., Schaufeli, W. B. (2012). 
Measuring Spirituality as a Universal Human Experience: A Review of Spirituality Questionnaires. Journal of Religion and Health, Vol. 51, p. 336-354.

Eliade, M. (1961). The Sacred and the Profane. New York: Harper \& Row.

Ellison, C. (1983). Spiritual well-being: Conceptualization and measurement. Journal of Psychology and Theology, Vol. 11, p. 330-341.

Elkins, D. N., Hedstrom, L. J., Hughes, L. L., Leaf, J. A., Saunders, C. (1988). Toward a HumanisticPhenomenological Spirituality: Definition, Description, and Measurement. Journal of Humanistic Psychology, Vol. 28, p. 5-18.

Elkins, D. N. (1998). Beyond Religion: A Personal Program for Building a Spiritual Life Outside the Walls of Traditional Religion. Wheaton, Illinois: Quest Books.

Elkins, D. N. (2015). Beyond Religion: Toward a Humanistic Spirituality. In K. J. Schneider, J. F. T. Bugental, J. F. Pierson (eds.). The Handbook of Humanistic Psychology, p. 681-692. California: Sage Publications, Inc.

Goldstein, K. (1995). The Organism: A Holistic Approach to Biology Derived from Pathological Data in Man. New York: Zone Books.

Hay, D., Nye, R. (2006). The Spirit of the Child. London: Jessica Kingsley Publishers

Howden, J. W. (1992). Development and psychometric characteristics of the Spirituality Assessment Scale. Doctoral Dissertation. Texas Women's University.

Humanist Manifestos I, II and III. (2003). Washington, DC: American Humanist Association. Prieiga internete: http://www.onthewing.org/user/Apo_Humanist\%20Manifesto\%20I-II-III.pdf.

Ivtzan, I., Chan, C. P., Gardner, H. E., Prashar, K. (2013). Linking religion and spirituality with psychological well-being: examining self-actualisation, meaning in life, and personal growth initiative. Journal of Religion and Health, Vol. 52, p. 915-929.

Young-Eisendrath, P., Miller, M. E. (2000). Beyond enlightened self-interest: The psychology of mature spirituality in the twenty-first century. In P. Young-Eisendrath, M. E. Miller (eds.). The psychology of mature spirituality. Integrity, wisdom, transcendence, p. 1-7. London: Routledge.

Jones, A., Crandall, R. (1986). Validation of a short index of self-actualization. Personality and Social Psychology Bulletin, Vol. 12, p. 63-73.

Jovaiša, L. (1998). Apie mūsu būtį. Vilnius: Agora.

Kant, I. (1998). Critique of Pure Reason. Cambridge: Cambridge University Press.

Kant, I. (2011). Groundwork of the Metaphysics of Morals: A German-English Edition. Cambridge: Cambridge University Press.

Kapuscinski, A. N., Masters, K. S. (2010). The Current Status of Measures of Spirituality. Psychology of Religion and Spirituality, Vol. 2, p. 191-205.

Kass, J. D., Friedman, R., Leserman, J., Zuttermeister, P. C., Benson, H. (1991). Health outcomes and a new index of spiritual experience. Journal for the Scientific Study of Religion, Vol. 30, p. 203-211.

Kontrimienè, S. (2018). Humanistinio dvasingumo ryšys su auklejjimo šeimoje patirtimis. Daktaro disertacija. Vilnius: Vilniaus universiteto leidykla.

Leclerc, G., Lefrançois, R., Dubé, M., Hébert, R., Gaulin, P. (1999). Criterion validity of a new measure of selfactualization. Psychological Reports, Vol. 85, p. 1167-1176.

Lurie, Y. (2006). Tracking the Meaning of Life: a Philosophical Journey. Missouri: University of Missouri Press.

MacDonald, D. A., Friedman, H. L., Kuentzel, J. G. (1999). A survey of measures of spiritual and transpersonal constructs: Part one: Research update. Journal of Transpersonal Psychology, Vol. 31, p. 137-154.

MacDonald, D. A. (2000). Spirituality: Description, measurement and relation to the Five Factor Model of personality. Journal of Personality, Vol. 68, p. 153-197.

MacDonald, D. A., Gagnier, J. J., Friedman, H. L. (2000). The Self Expansiveness Level Form: Examination of its validity and relation to the NEO Personality Inventory-Revised. Psychological Reports, Vol. 86, p. 707-726.

MacDonald, D. A. (2009). Identity and Spirituality: Conventional and Transpersonal Perspectives. International Journal of Transpersonal Studies, Vol. 28, p. 86-106.

Martišauskienė, E. (2004). Paauglių dvasingumas kaip pedagoginis reiškinys. Vilnius: VPU.

Martišauskienè, E. (2008). Šviesos pedagogikos kontūrai: dvasingumo ugdymo pamatai. Vilnius: VPU.

Maslow, A. H. (1993). The farther reaches of human nature. New York: Penguin/Arkana.

Maslow, A. H. (1999). Toward a psychology of being. New York: Wiley. 
Maslow, A. (2009). Motyvacija ir asmenybè. Vilnius: Apostrofa.

Miller, J. P., Nakagawa, Y. (2002). Nurturing our wholeness: Perspective on spirituality in education. Brandon, VT: Foundation for Educational Renewal.

Moberg, D. O. (2002). Assessing and measuring spirituality: Confronting dilemmas of universal and particular evaluative criteria. Journal of Adult Development, Vol. 9, p. 47-60.

Otto, R. (1961). The Idea of the Holy. New York: Oxford University Press.

Otway, L. J., Carnelley, K. B. (2013). Exploring the associations between adult attachment security and selfactualization and self-transcendence. Self and Identity, Vol. 12, p. 217-230.

Piedmont, R. L. (1999). Does spirituality represent the sixth factor of personality? Spiritual transcendence and the five factor model. Journal of Personality, Vol. 67, p. 985-1013.

Piedmont, R. L. (2001). Spiritual Transcendence and the Scientific Study of Spirituality. Journal of Rehabilitation, Vol. 67, p. 4-11.

Reed, P. (1992). An emerging paradigm for the investigation of spirituality in nursing. Research in Nursing and Health, Vol. 15, p. 349-357.

Scheler, M. (1973). Formalism in Ethics and Non-Formal Ethics of Values. Evanston, IL: Northwestern University Press.

Schneider, K. J., Bugental, J. F. T., Pierson, J. F. (2015). Introduction. In K. J. Schneider, J. F. T. Bugental, J. F. Pierson (eds.). The Handbook of Humanistic Psychology, p. xix-xvi. California: Sage Publications, Inc.

Shostrom, E. L., Knapp, R. R. (1976). Validation of the Personal Orientation Dimensions: An inventory for the measurements of self actualizing. Educational and psychological measurements, Vol. 36, p. 491-494.

Sinetar, M. (2000). Spiritual intelligence: What we can learn from the early awakening child. Maryknoll, N.Y: Orbis Press.

Steger, M. F., Frazier, P., Oishi, S., Kaler, M. (2006). The meaning in life questionnaire: Assessing the presence of and search for meaning in life. Journal of Counseling Psychology, Vol. 53, p. 80-93.

Sumerlin, J. R., Bundrick, C. M. (1996). Brief Index of Self-Actualization: A Measure of Maslow's Model. Journal of Social Behavior \& Personality, Vol. 11, p. 253-271.

Thatcher, A. (1996). 'Policing the sublime': a wholly (holy?) ironic approach to the spiritual development of children. In J. Astley, L. J. Francis (eds.). Christian Theology and Religious Education. London: SPCK.

Vasconcellos, J. (2015). Foreword. In K. J. Schneider, J. F. T. Bugental, J. F. Pierson (eds.). The Handbook of Humanistic Psychology, p. xiii-xiv. California: Sage Publications, Inc.

Westphal, M. (2004). Transcendence and Self-Transcendence: on God and the Soul. Bloomington: Indiana University Press.

WHOQOL and Spirituality, Religiousness and Personal Beliefs (SRPB). (1998). Switzerland: World Health Organization.

Wolman, R. (2001). Thinking Without Your Soul - Spiritual Intelligence and Why It Matters. New York: Random House, Inc.

\section{ASSESSMENT OF SPIRITUALITY: DEVELOPMENT AND VALIDATION OF THE HUMANISTIC SPIRITUALITY INVENTORY}

\section{Simona Kontrimienè}

Summary

Spirituality is a complex multidimensional phenomenon whose definitions are very diverse. Although currently there exists a considerable degree of variability in the models of spirituality and its measures, there are certain commonalities shared 
by all the proposed views, notably belief in the Higher Power (often referred to as transcendence), meaning in life as well as other components of spirituality which capture the aspects of innerness, selflessness, self-fulfllment and depth, broadness and maturity of thinking. All those most salient constituents are included in the proposed Humanistic Spirituality Model, which captures the content domain of spirituality through three components (self-actualisation, transcendence and ultimate meaning in life) and rests on the writings of Abraham Maslow (2009 [1954], 1999 [1961], 1993 [1971]), David Elkins (2015; Elkins et al., 1988), Merold Westphal (2004) and others.

The model served as the basis for the development of the Humanistic Spirituality Inventory (HSI), a 40-item measure of humanistic spirituality which contains three scales corresponding to the three model components: Self-Actualisation (23 items, e.g.: "I believe that even the biggest blows in life would not break me"), Transcendence (9 items, e.g.: "I often engage in deep reflection, meditation and/or prayer") and Ultimate Meaning in Life (8 items, e.g.: "My faith allows me to see meaningful ties among things which are not directly related"). Self-actualisation implies efficient perception of reality, spontaneity, creativity, peak experiences, personal growth, detachment, Gemeinschaftsgefühl (social interest) and profound relationships; transcendence is viewed as a belief that there is something more than "what is seen", or belief in the Higher Power, it also implicates self-transcendence and a holistic view of reality; ultimate meaning in life implies a highly meaningful life or a sense of purposefulness and ontological significance inspired by faith.

The current study $(N=331)$ explores the psychometric properties of the instrument and has found the following: First, a higher than $90 \%$ agreement among the four judges who rated the inventory on the appropriateness of the items suggests adequate content validity of the instrument. Second, a confirmatory factor analysis, which has yielded three factors much in line with the Self-Actualisation, Transcendence and Ultimate Meaning in Life scales, as well as substantial and statistically significant correlations with other measures of the constructs (ranging from .401 to .814) prove adequate construct validity of the scales. Third, the measure has been found to have good internal consistency reliability, with Cronbach's alphas of .87 for the total Humanistic Spirituality Inventory, .72 for the Self-Actualisation Scale, .80 for the Transcendence and .80 for the Ultimate Meaning in Life Scale. Lastly, the inventory has acceptable test-retest reliability (.92 over a two-week period).

The results of the study support the good psychometric properties of the Humanistic Spirituality Inventory, which suggests that it can be used as a proper measure in spirituality research. We believe the proposed model and inventory validated in the current study reflect experiences of individuals from different religious affiliations and are suitable for today's Western culture, where most people increa- 
singly find contact with divinity within themselves and purify the meaning of life through their own idiosyncratic spiritual experiences. The Humanistic Spirituality Model is coincident with ideas expressed by de Jager Meezenbroek and colleagues (2012), according to which most current instruments of spirituality measure universal experiences such as connectedness with nature, compassion, gratitude, mystical experiences and self-actualisation, and the essential component of spirituality is relatedness. In our model, relatedness with oneself, others and nature (which corresponds to the component of self-actualisation and often manifests through inner harmony, serenity, conscientiousness, self-awareness, compassion and care) and relatedness to what is transcendent (a connection with something beyond that which is merely human, for example, the universe, the transcendent reality, the Higher Power or God and expressed through awe, hope and holiness) make for the formation of the perception of ultimate meaning in life, the ability that is acquired through meditation, prayer and/or deep reflection and is contingent on the level of internalisation of the highest Being-values. 
